\title{
Impact of External Job Mobility and Occupational Job Mobility on Earnings
}

\author{
Chan Wai Wong ${ }^{1}$ (D), Ming Yu Cheng ${ }^{2}$ (D), Teck Chai Lau ${ }^{2}$ \\ ${ }^{1}$ KDU University College (Malaysia) \\ ${ }^{2}$ Universiti Tunku Abdul Rahman (Malaysia) \\ cw.wong@,kdu.edu.my, chengmy@utar.edu.my,Llaut@@utar.edu.my
}

Received: April 2016

Accepted: July 2016

\section{Abstract:}

Purpose: The purpose of the study is to examine the relationship between external job mobility and occupational job mobility on earnings among engineers in Malaysia.

Design/methodology/approach: Using curricular vitae data from a job agency, this paper tracks job mobility through job histories and examine how it affects earnings.

Findings: Results obtained from regression analysis indicate that higher external job mobility will contribute to higher earnings, but occupational mobility will have adverse effect on earnings.

Research limitations/implications: Limitation of the study is that the results are extrapolated from a self-report dataset.

Practical implications: Nonetheless, the results give important implications to the Malaysian job market on how firm-specific skills and occupational specific skills are rewarded among engineers who actively seek for alternative employment online, and a guide to job applicants in career planning.

Originality/value: The findings has also revealed important variables to be included in explaining high skill labor earnings in the context of Malaysian engineers, it serves as an important reference for future in modeling earnings. 
Keywords: careers, employee turnover, job mobility, earnings, recruitment

\section{Introduction}

The role of job mobility in human capital development literature yields mixed results. Job mobility has received considerable attention in studies related to salary attainment on individual career progression (Ng, Sorensen, Eby \& Feldman, 2007). Some studies have suggested that individuals who have undergone inter-firm mobility experienced higher career and income progressions as compared to their counterparts who did not (Lam, Ng \& Feldman, 2012; Brett \& Stroh, 1997; Ghosh, 2007; Lam \& Dreher, 2004). Talent mobility is considered an essential part of firm's growth, innovativeness and survival (Beckman, 2006). Job mobility is not uncommon in developed economies mainly because of the competition for highly skilled labour resulted in greater opportunity for job mobility. Moreover, the socio economic status of the developed countries and firms make talent mobility more attractive for high skill labour (Harvey \& Groutsis, 2015). The phenomenon is also influenced by their recruitment practice where many employees serve on short term employment contract, and employees who could not adapt to the latest marketable skills are more prone to be discontinued after the contract term (Fuller, 2008; Ossorio \& Hunsucker, 1989).

On the other hand, some had argued that commitment to an organisation proves to be beneficial for individual's career development as well as firm performance (Munasinghe \& Sigman, 2004; Abdul-Rashid, Sambasivan \& Johari, 2003; Jaramillo, Mulki \& Marshall, 2005). From the human resources management perspective, the argument is mainly based on the retention and preservation of firm specific skills and talent in firms (Becker, 1962) as well as negative consequences and cost for firms resulting from talent turnover (Warn, 1994; Wright \& Kehoe, 2008).

While many research linking job mobility and salary attainment focused on developed countries, research on job mobility and income is rather limited in developing countries such as Malaysia. With Malaysia's aspiration to become an advanced and high income nation by year 2020, the Malaysian government sees human capital development as one of the strategic thrusts to support this vision. As shown in the Eleventh Malaysia Plan, it emphasises on up skilling as well as reskilling Malaysia talents as means to transform Malaysian economy towards knowledge-intensive activities. Hence, studies of job mobility and how it would contribute to human capital development and earnings are timely studies for Malaysia.

As the definition of human capital development varies, this paper takes Neal's (1995) view on industrial specific skills development of workers as primary indicator of human capital development. While each 
training and skills have their own merits, the question is how employers in Malaysia reward their employees based on firm-specific skills and occupational specific skills. In other words, it is vital to know whether Malaysia labour market rewards workers with higher job mobility, or the ones who have long commitment to an organisation, with or without a variety of occupational experiences. Each result would present important implications on wage growth based on firm specific or occupational specific human capital development and job mobility in Malaysia.

As recruitment is generally done on an ad-hoc basis in Malaysia, it encourages higher job mobility (Hooi, 2008), but the impact of job mobility on earnings in Malaysia is little known. It may not result in significant increase in earnings as what happened in the developed countries, since the developing countries may not have enough resources to compete and compensate high skill labour in the country. With the significant growth of tertiary educated workers $(6.05 \%$ of employed person with tertiary education in 1983 to $24.68 \%$ in 2013) over the past 30 years (Department of Statistics Malaysia, 2015), and higher job turnover rate compared to the past in various sectors in Malaysia (Salleh, Nair \& Harun, 2012; Juhdi, Pa'wan \& Hansaram, 2013), it will be crucial to find out whether job mobility has significant impact on earning in Malaysia.

There have been signs showing Malaysian firms have difficulties in retaining their talented engineers (Rahman, 2012). As engineering profession is one of the occupations within the field of science and technology, which is pioneering in driving innovation and national development, this paper has chosen this profession as the focus of the study and seeks to answer the following few questions:

Research question 1: How would external job mobility (JM) affect engineers' earnings in Malaysia?

Research question 2: What is the impact of occupational job mobility (OM) on engineers' earning?

Research question 3: Do external job mobility and occupational job mobility affects earnings differently?

\section{Literature Review}

\subsection{Human Capital Theory and Earnings}

Human capital theory reveals that work related capabilities are developed through informal and formal education, training, experience, and job mobility in the labour market. The theory supports the notion that job mobility is positively related to earning progression as diverse working experience helps accumulate additional individual human capital. Job mobility is viewed as one of the individual investment decisions to obtain additional human capital from diverse firms (Mincer \& Jovanovic, 1981; Mincer, 1984). However, investment in job mobility diminishes over time because the time to use the diverse 
working experience shortens as an individual aged; also the opportunity cost of learning in different job is likely to increase over time. The claims are further substantiated by Borjas (1981) where less mobile older workers' earning are significant higher than their more mobile counterparts, albeit job mobility does increase wage significantly.

Although human capital theory encourages job mobility to increase earnings, but the mobility advantages may only be limited to early stages of career lifecycle. The argument of negative consequences in late stage is with the assumption that firm specific training is less likely to be transferable. This assumption may not be so applicable in the current employment trend that encourages integration of talents as well as knowledge transfer through inter-firm mobility.

Recent studies on job mobility show that external job mobility, generally defined as an individual moving from one organisation to another, is strongly related to higher earnings (Lam et al., 2012; Murrell, Frieze, \& Olson, 1996; Topel \& Ward, 1992), increased employee and firms performance (Mion \& Opromolla, 2014), career advancement (Acosta, 2010; Ghosh, 2007; Sicherman \& Galor, 1990; Lazear, 2004) as well as encourage knowledge transfer and learning (Bienkowska, Lundmark \& Malmberg, 2011; Cooper, 2001). Other than that, development of social capital as a part of human capital development could take place through job mobility. Social capital theory endorses the notion that social capital could potentially increase employee's performance and may possibly lead to increased earnings in the market (Coleman, 1988; Schmutte, 2015; Bäker, 2015) Therefore, it is hypothesized that:

\section{Hypothesis 1: Higher external job mobility is significantly related to higher earnings.}

Although diverse working experience is commended in human capital theory, it is also argued that earnings will progress positively only if job mobility occurs within the same industry and same occupation, implying that occupational mobility is negatively related to earning progression (Gius, 2014; Neal, 1995). It costs firms more on investment training to train an employee who undergoes occupational mobility, because human capital investment is closely related to the returns of the workers' productivity in the remaining working period. If the training cost is higher than expected productivity gain, an employee who experienced occupational mobility is less likely to be rewarded with higher salary as the cost of training is higher compared to those who stayed within the same industry and occupation (Kambourov, Manovskii \& Plesca, 2012; Mincer, 1962; Ben-Porath, 1967; Becker, 1962).

However, there are studies indicating the current trend of employment favouring integration of specialities in talent management, where knowledge of diverse occupational capabilities should be appreciated to enhance organisational effectiveness (Levenson, 2012; Eamets \& Jaakson, 2014; Roosaar, Mõtsmees \& Varblane, 2014). Whether firms appreciate specialisation or integration of capabilities for 
engineers in Malaysia remained an issue to be explored. Therefore, this leads the study to hypothesize that:

\section{Hypothesis 2: Occupational mobility is significantly related to earnings.}

Generally, external job mobility indicates reduced firm specific human capital, and occupational mobility indicates reduced occupational specific human capital. Hence, Hypothesis 3 aims to test the different effects of external and occupational mobility on earning

\section{Hypothesis 3: External job mobility and occupational mobility affect earnings differently.}

\subsection{Social Demographic Factors and Earnings}

Other than work related attributes, factors that are not directly related to productivity sometimes do affect an individual's earnings. In particular, social demographic factors like age, gender, education and ethnic group are closely related to earnings (Vardi, 1980; Carless \& Arnup, 2011; Mincer, 1974).

As mentioned in the previous section, firms are less likely to invest in older workers compared to younger workers since their remaining time of contribution to the firm reduces with age. In addition, employees face reduced financial and non-financial incentives and increasing mobility costs as one aged. Therefore, older workers are likely to be less mobile in the job market (Groot \& Verberne, 1997). However, it does not mean that older workers have less opportunity to have higher earnings compared to their younger counterparts, as working experience remain essential in determining earnings. It should be noted that it is vital to distinguish between age and working experience as the two factors do not always draw the same implications in different occupations. An older worker does not necessary have sufficient experience in a particular field if occupational mobility is high throughout the career path. Therefore, a firm's decision in recruiting and investing in experienced human capital is based on working experience in a specific field rather than a worker's age. Senior workers who are lacking of firm or occupational specific skills and knowledge are less in demand (Klevmarken \& Quigley, 1976).

Gender plays a vital role in determining success and earnings in the engineering profession as it is often perceived that engineering is a masculine profession, thus, the jobs are deemed more suited for males (Hatmaker, 2013; Powell, Dainty \& Bagilhole, 2012; González-Ramos \& Bosch, 2013). Aside from underrepresentation of female in engineering profession, females are often found or perceived to have weaker performance and higher drop-out rate in engineering programmes in higher education institutions (Arastoopour, Chesler \& Shaffer, 2014; Felder, Felder, Mauney, Hamrin \& Dietz, 1995). With these 
backgrounds, the paper will examine whether gender play an important role in determining Malaysian engineers' earnings.

\section{Method}

\subsection{Sample}

The primary criterion of sample selection is the occupation, where only engineers will be selected for the study. More specifically, the selection is confined to Malaysian engineers who are actively seeking for alternative employment through online job portals. Education is a controlled variable where selected samples must attain at least a tertiary education.

All data were updated as of year 2014. Several online recruitment agencies were contacted but they were unable to participate, including Jobstreet.com., which is one of the pioneer and largest online recruitment agencies in Malaysia. JobsCentral Malaysia is the only company which is able to participate and provide the data needed for this study. In terms of registered jobseeker, JobsCentral Malaysia has more than 700,000 jobseekers with estimated 30,000 increase of jobseekers per month as of August 2015 (confirmed through media kit by JobsCentral Malaysia), whereas Jobstreet.com had about 2 million jobseekers in its database in 2013 (BFM, 2013).

Samples were randomly selected to collect updated curricular vitae (CV) to examine job mobility of Malaysian engineers. A total of 666 samples of Malaysian engineers with at least a bachelor degree in engineering were used in the analysis. The data were filtered by JobsCentral Malaysia to ensure there is no breach of research ethical codes and that it adheres to Personal Data Protection Act (PDPA) 2010. Hence, all personal information remained confidential and they are not accessible by researchers.

\subsection{Procedures}

Only updated information required for the study are collected. Job title and duration for each were recorded to examine working experience and job mobility. Other demographic details were also recorded for further analysis. 


\subsection{Analytical Model}

The paper attempts to analyse the relationship between job mobility and earnings, in addition to the other variables established in the Mincer's model. Hierarchical multiple regression analysis is used to examine the relationship between the study variables. The analytical model is shown below, variables are chosen based on human capital theory and literature review:

$$
\begin{gathered}
\text { Earnings }=\alpha+\beta 1 \text { Age }+\beta 2 \text { Working Experience }+\beta 3 \text { External Job Mobility }+ \\
\beta 4 \text { Occupational Mobility }+\beta 5 \text { Gender }+\varepsilon
\end{gathered}
$$

Age and working experience are measured in years, external job mobility and occupational mobility are measured in the number of job changes, and finally gender is measured as a dummy variable where female $=0$ and male $=1$.

\subsection{Definition of Terms and Data Management}

Job mobility is defined as external job mobility which involves changing organisation (Lam et al., 2012; $\mathrm{Ng}$ et al., 2007). It is measured by the number of job changes throughout an individual's career. Due to limitation of data, it will not specify whether the change is on voluntary basis.

Defining an individual's occupation as an engineer is based on two criteria, i.e. the education background should be engineering at a bachelor degree and/or above, and have at least one job experience in their career history worked as an engineer. The term engineer is defined according to the Malaysia Standard Classification of Occupations (MASCO) 2008.

Occupational mobility is defined by jobs that are not classified within the mentioned terminology. For example, if person A worked as an engineer in his first job but switched to be a banker in his second job, it will be counted as one occupational change.

The data collected contain certain difficulties such as ambiguous job title which makes it difficult to define certain professions. This research managed such constraints as below:

a) Research assistants, trainees, laboratory workers and interns are not classified as occupational mobility from engineering professions.

b) Generic titles such as "manager" or "supervisor" are classified as occupational mobility from previous profession. 
c) Professions which require engineering background knowledge such as sales engineer or auditors in engineering professions are not classified as occupational mobility from engineering professions.

Working experience is defined as the years of active working experience after tertiary education, thus it excludes years of working experience before an individual is qualified as an engineering. There are instances where a relatively aged individual may have relatively less years of working experience (e.g. aged 43 but had only 3 years working experience) compared to their counterparts. Although this might be explained by various reasons, such as taking a break from work, nevertheless the specific reasons of less working experience relative to age is not the focus of this study.

Earning is defined by the latest pre-taxed monthly salary paid to the samples, measured in Malaysian Ringgit (MYR).

\section{Results}

This section provides an overview of the sample characteristics and mobility trend. The second part reveals the results of the regression model and testing of the hypotheses mentioned above.

\subsection{Descriptive Statistics}

In Table 1, it shows that engineers who are actively seeking job through online portals earn a mean salary of MYR 6018.28, indicating these engineers can be classified as middle income earners in Malaysia (Economic Planning Unit, 2014). Engineers who seek for alternative employment are largely male in this sample. On average, engineers in the sample have about 8 years of working experience.

It should be noted that the respondents are mostly aged between 26 to 35 years old. It is consistent with Borjas (1981) and Mincer (1984) that incentives for older workers to change jobs are less compared to their younger counterparts, making older engineers less likely to move. 


\begin{tabular}{|c|c|c|c|c|c|c|c|}
\hline & $\begin{array}{l}\text { Sample } \\
\text { size }\end{array}$ & Male & Female & $\begin{array}{l}\text { Mean earnings } \\
\text { (MYR/month) }\end{array}$ & $\begin{array}{l}\text { Earnings } \\
\text { standard } \\
\text { deviation }\end{array}$ & $\begin{array}{c}\text { Mean } \\
\text { working } \\
\text { experience }\end{array}$ & $\begin{array}{l}\text { Working } \\
\text { experience } \\
\text { standard } \\
\text { deviation }\end{array}$ \\
\hline & 666 & 549 & 117 & 6018.28 & 3748.47 & 8.80 & 5.89 \\
\hline \multicolumn{8}{|c|}{ Age group } \\
\hline $26-30$ & 201 & 154 & 47 & 3682.00 & 1560.42 & 3.29 & 1.63 \\
\hline $31-35$ & 200 & 157 & 43 & 5607.00 & 2437.74 & 6.98 & 2.65 \\
\hline $36-40$ & 137 & 118 & 19 & 6814.00 & 2803.65 & 11.26 & 3.00 \\
\hline $41-45$ & 84 & 79 & 5 & 8876.00 & 5227.57 & 15.96 & 3.21 \\
\hline $46-50$ & 44 & 41 & 3 & 10739.00 & 5814.03 & 21.90 & 4.17 \\
\hline
\end{tabular}

Table 1. Sample characteristics

Table 2 shows the central tendency of job mobility. On average, these engineers have changed about 1.5 jobs throughout their career cycles. Most of the engineers did not move in the early stage of their career life, job mobility mainly happened after they have accumulated certain years of working experience, when they are at least 31 years old and above. Most of the engineers chose not to have occupational mobility. It should also be noted that not all engineers who are actively seeking for employment in the sample had previously moved in their career, only $4.5 \%$ of the sample have experience changing occupation in their employment history.

\begin{tabular}{|c|c|c|c|c|c|c|c|c|}
\hline \multirow[b]{4}{*}{ Age grou } & \multicolumn{2}{|c|}{$\begin{array}{l}\text { Mean (Total mobility } \\
\text { count/ number of } \\
\text { sample) }\end{array}$} & \multicolumn{2}{|c|}{ Mode } & \multicolumn{2}{|c|}{ Median } & \multicolumn{2}{|c|}{ Number } \\
\hline & JM & OM & JM & OM & JM & OM & JM & OM \\
\hline & 1.51 & 0.05 & 0.00 & 0.00 & 1.00 & 0.00 & 417 & 30 \\
\hline & & & & & & & & \\
\hline $26-30$ & 0.83 & 0.04 & 0.00 & 0.00 & 0.00 & 0.00 & 96 & 8 \\
\hline $31-35$ & 1.46 & 0.06 & 0.00 & 0.00 & 1.00 & 0.00 & 130 & 9 \\
\hline $36-40$ & 1.98 & 0.03 & 0.00 & 0.00 & 2.00 & 0.00 & 97 & 4 \\
\hline $41-45$ & 1.94 & 0.01 & 0.00 & 0.00 & 2.00 & 0.00 & 59 & 1 \\
\hline $46-50$ & 2.54 & 0.20 & 2.00 & 0.00 & 2.00 & 0.00 & 35 & 8 \\
\hline
\end{tabular}

Table 2. Job mobility descriptive statistics 


\subsection{Relationships between Job Mobility and Earnings of Malaysian Engineers}

Prior to running the regression analysis, it is suspected that multicollinearity could be an issue since age and working experience are highly correlated in nature. Correlation analysis and collinearity diagnosis were conducted and it is found that the Variance Inflation Factor (VIF) is less than 10, within the acceptable level for regression analysis, therefore both age and working experience will be included in the regression model (see Appendix).

To test the hypotheses mentioned in section 2 , hierarchical multiple regression is used to examine the impact of job mobility on earnings as shown in Table 3. Model 1 examines effects of control variables (age, working experience and gender) on earning (Mincer equation). Education is not included in the model as all respondents' education levels are controlled at tertiary education and above. The adjusted Rsquare is 0.409 with only working experience being significant at 1 percent level.

Model 2 includes both external job mobility and occupational mobility factors in addition to the control variables. At 5 percent level of significance, both mobility factors are found to be significant in explaining earnings of engineers. It is also found that higher external job mobility has a significant positive effect on earnings while occupational mobility has significant negative impact, the findings highlight the different effects of two job mobility factors on earnings. Adjusted R-square in Model 2 has increased by 0.027 , implying job mobility factors are relevant variables to be included in the model to increase the explanatory power of the earnings model.

Model 2 has highlighted the positive effect of external job mobility on earnings. However, as argued by Lam, Ng and Feldman (2012), higher external job mobility may not necessary contribute to higher earnings, unless it is accompany by working experience. In other words, job-hopping without accumulation of working experience may not be beneficial. In order to test this hypothesis, an interaction term consists of working experience and external job mobility is included Model 3 for analysis. The results indicate similar results as Model 2, and the interaction term is insignificant. 
Main effects

\section{$\beta$ (ln Earning)}

\begin{tabular}{|c|r|r|r|}
\hline Age & $0.004(0.041)$ & $0.007(0.075)$ & $0.007(0.079)$ \\
\hline Working Experience & $0.054^{* *}(0.596)$ & $0.046^{* *}(0.502)$ & $0.049^{* *}(0.541)$ \\
\hline External Job Mobility & & $0.063^{* *}(0.186)$ & $0.088^{* *}(0.262)$ \\
\hline Occupational mobility & & $-0.152^{*}(-0.070)$ & $-0.151^{*}(-0.069)$ \\
\hline Gender $\boldsymbol{N}$ & $0.045(0.032)$ & $0.021(0.015)$ & $0.020(0.014)$ \\
\hline $\begin{array}{c}\text { Interaction effect } \\
\text { Working experience x } \\
\text { External Job Mobility }\end{array}$ & & & $-0.002(-0.109)$ \\
\hline Adjusted $\boldsymbol{R}^{2}$ & & & 0.435 \\
\hline
\end{tabular}

$\alpha$ Gender: $0=$ Female, $1=$ Male

$* \mathrm{p}<.05 ; * * \mathrm{p}<.01$

Numbers in bracket are standardized beta coefficient

Table 3. Multiple regression analysis of study variables on earnings

\section{Discussion}

Modifying from Mincer (1984) human capital model, but controlled for the education factor, this study examines the impact of age, working experience, external job mobility and occupational mobility on earnings of engineers in Malaysia. The findings indicate that external job mobility is positively related to earnings (Lam et al., 2012; Murrell et al., 1996; Topel \& Ward, 1992) while occupational mobility is negatively related to earnings (Gius, 2014; Neal, 1995). This implies that, generally employers in Malaysia are willing to give more rewards to engineers who have working experience in more than one organisation. This could be due to engineering skills are either transferrable or could be assimilated into new organisations easily. Thus, firm specific skills may not be the determining factor in earnings for engineers who are actively seeking for alternative employment in this study. Nevertheless, occupational mobility is negatively related to earnings, it indicates that occupational specific skills are vital in deciding an engineer's earnings. This is an important finding as it emphasises the importance for engineers to stay in the engineering profession in order to earn a higher salary.

Working experience remains the primary factor contributing to earnings in this study, followed by external job mobility. One of the interesting findings in Table 3 is that age appears to be insignificant factor in the equation. It shows firms prefer to compensate those with working experience over age although the two factors could be interrelated. This concurs with Mincer (1984) that firms would invest in younger workers compared to older workers given they have similar working experience. It further confirmed the need to separate age and working experience as different factors contributing to earnings (Klevmarken \& Quigley, 1976). 
Insignificant results of interaction term (working experience $\mathrm{x}$ external job mobility) in Model 3 suggested that external job mobility may not need to rely on working experience to have an effect on earnings. It implies that compensation based on job mobility happens in all career stages, regardless of the accumulated years of experience.

\section{Conclusion and Limitation}

External job mobility is found to be an important factor contributing to earnings in Malaysia's engineering job market. Nevertheless, working experience remains the primary factor contributing to earnings. Graduates from engineering schools are advised not to move out from the engineering profession as it could potentially give negative signals to employers and in turn affects earnings.

The findings indicate that external job mobility led to higher earnings. Engineers who wish to earn more should be more mobile in the job market to learn different skills from different organisation and to enrich their profiles. For employers, it is crucial for them to develop strategic human resource management to handle more mobile talents.

A major limitation of this study is data limitation. As job histories are self-report in nature, there is limitation on the authenticity of the record. It is possible that the information indicated in the CVs is used to maximise the chances of employment opportunities and histories that could induce negative perceptions by employers are selectively removed by job applicants. Nevertheless, the CVs require applicants to name the organisations in the job histories and referees contact details are required by the job search website for employer's reference. Although it is still possible for the applicants to remove certain negatively perceived short-term employment histories, the likelihood for the job applicants to forge their job histories is relatively low because it is relatively easy for the potential employer to check its authenticity.

Another limitation is that this study has not taken ethnic group into account as Malaysia is known to have ethnic oriented social economic differences in her historical background. This is because there are little job applicants indicated their ethnic group in the data collected, more ethnic based compensatory analysis is needed in future Malaysia's job market research. 


\section{Acknowledgements}

This work was supported by a research grant from KDU University College (KDURG/2014/1/006). We would like to extend our gratitude to Professor Carol Hooi Lai Wan for her useful comment on an earlier version of this article, and JobsCentral Malaysia's staffs for their assistance on data collection.

\section{References}

Abdul-Rashid, Z., Sambasivan, M., \& Johari, J. (2003). The influence of corporate culture and organisational commitment on performance. Journal of Management Development, 22(8), 708-728. http://dx.doi.org/10.1108/02621710310487873

Acosta, P. (2010). Promotion dynamics the Peter Principle: Incumbents vs. external hires. Labour Economics, 17(6), 975-986. http://dx.doi.org/10.1016/j.labeco.2010.02.005

Arastoopour, G., Chesler, N.C., \& Shaffer, D.W. (2014). Epistemic persistence: A simulation-based approach to increasing participation of women in engineering. Journal of Women and Minorities in Science and Engineering, 20(3). http://dx.doi.org/10.1615/JWomenMinorScienEng.2014007317

Bäker, A. (2015). Non-tenured post-doctoral researchers' job mobility and research output: An analysis of the role of research discipline, department size, and coauthors. Research Policy, 44(3), 634-650. http://dx.doi.org/10.1016/j.respol.2014.12.012

Becker, G.S. (1962). Investment in human capital: A theoretical analysis. The Journal of Political Economy, 70(5), 9-49. http://dx.doi.org/10.1086/258724

Beckman, C.M. (2006). The influence of founding team company affiliations on firm behavior. Academy of Management Journal, 49(4), 741-758. http://dx.doi.org/10.5465/AMJ.2006.22083030

Ben-Porath, Y. (1967). The production of human capital and the life cycle of earnings. The Journal of Political Economy, 75(4), 352-365. http://dx.doi.org/10.1086/259291

BFM (2013). Gig seek, goes online. Retrieved July $24^{\text {th }}$, 2014, from: http://www.bfm.my/breakfast-grille-adrian-chngjobsdb.html

Bienkowska, D., Lundmark, M., \& Malmberg, A. (2011). Brain circulation and flexible adjustment: Labour mobility as a cluster advantage. Geografiska Annaler: Series B, Human Geography, 93(1), 21-39. http://dx.doi.org/10.1111/j.1468-0467.2011.00359.x 
Borjas, G.J. (1981). Job mobility and earnings over the life cycle. Industrial \& Labor Relations Review, 34(3), 365-376. http://dx.doi.org/10.1177/001979398103400303

Brett, J.M., \& Stroh, L.K. (1997). Jumping ship: Who benefits from an external labor market career strategy? Journal of Applied Psychology, 82(3), 331. http://dx.doi.org/10.1037/0021-9010.82.3.331

Carless, S.A., \& Arnup, J.L. (2011). A longitudinal study of the determinants and outcomes of career change. Journal of Vocational Behavior, 78(1), 80-91. http://dx.doi.org/10.1016/j.jvb.2010.09.002

Coleman, J.S. (1988). Social capital in the creation of human capital. American Journal of Sociology, 94, S95-S120. http://dx.doi.org/10.1086/228943

Cooper, D.P. (2001). Innovation and reciprocal externalities: information transmission via job mobility. Journal of Economic Behavior \& Organization, 45(4), 403-425. http://dx.doi.org/10.1016/S0167-2681(01)00154-8

Department of Statistics Malaysia (2015). Labour force survey time series data. Retrieved from: https://www.statistics.gov.my/index.php?r=column/ctimeseries\&menu id=NHJlaGc2Rlg4ZXIGTjh1SU1kaWY5UT09 (Accessed: January 2016).

Eamets, R., \& Jaakson, K. (2014). Labour market flexibility and spatial mobility. International Journal of Manpower, 35(6), 746-752. http://dx.doi.org/10.1108/IJM-05-2014-0123

Economic Planning Unit (2014). Table 3-Median Monthly Gross Household income by Ethnic Group, Strata and State, Malaysia, 1970-2014. Retrieved from: http://www.epu.gov.my/en/household-income-poverty (Accessed: January 2016).

Felder, R.M., Felder, G.N., Mauney, M., Hamrin, C.E., \& Dietz, E.J. (1995). A longitudinal study of engineering student performance and retention. III. Gender differences in student performance and attitudes. Journal of Engineering Education Washington, 84, 151-164. http://dx.doi.org/10.1002/j.21689830.1995.tb00162.x

Fuller, S. (2008). Job mobility and wage trajectories for men and women in the United States. American Sociological Review, 73(1), 158-183. http://dx.doi.org/10.1177/000312240807300108

Ghosh, S. (2007). Job mobility and careers in firms. Labour Economics, 14(3), 603-621. http://dx.doi.org/10.1016/j.labeco.2006.07.001

Gius, M. (2014). The impact of job mobility on earnings: using occupational and industrial classifications to identify job changes. International Review of Applied Economics, 28(2), 181-190. 
González-Ramos, A.M., \& Bosch, N.V. (2013). International mobility of women in science and technology careers: shaping plans for personal and professional purposes. Gender, Place \& Culture, 20(5), 613-629. http://dx.doi.org/10.1080/0966369X.2012.701198

Groot, W., \& Verberne, M. (1997). Aging, job mobility, and compensation. Oxford economic papers, 49(3), 380-403. http://dx.doi.org/10.1093/oxfordjournals.oep.a028615

Harvey, W.S., \& Groutsis, D. (2015). Reputation and talent mobility in the Asia Pacific. Asia Pacific Journal of Human Resources, 53(1), 22-40. http://dx.doi.org/10.1111/1744-7941.12047

Hatmaker, D.M. (2013). Engineering identity: Gender and professional identity negotiation among women engineers. Gender, Work \& Organization, 20(4), 382-396. http://dx.doi.org/10.1111/j.14680432.2012.00589.x

Hooi, L.W. (2008). The adoption of Japanese recruitment practices in Malaysia. International Journal of Manpower, 29(4), 362-378. http://dx.doi.org/10.1108/01437720810884764

Jaramillo, F., Mulki, J.P., \& Marshall, G.W. (2005). A meta-analysis of the relationship between organizational commitment and salesperson job performance: 25 years of research. Journal of Business Research, 58(6), 705-714. http://dx.doi.org/10.1016/j.jbusres.2003.10.004

Juhdi, N., Pa'wan, F., \& Hansaram, R. M. K. (2013). HR practices and turnover intention: The mediating roles of organizational commitment and organizational engagement in a selected region in Malaysia. The International Journal of Human Resource Management, 24(15), 3002-3019. http://dx.doi.org/10.1080/09585192.2013.763841

Kambourov, G., Manovskii, I., \& Plesca, M. (2012). Occupational mobility and the returns to training (No. tecipa-444).

Klevmarken, A., \& Quigley, J.M. (1976). Age, experience, earnings, and investments in human capital. The Journal of Political Economy, 84(1), 47-72. http://dx.doi.org/10.1086/260409

Lam, S.S., \& Dreher, G.F. (2004). Gender, extra-firm mobility, and compensation attainment in the United States and Hong Kong. Journal of Organizational Behavior, 25(7), 791-805.

http://dx.doi.org/10.1002/job.264

Lam, S.S., Ng, T.W., \& Feldman, D.C. (2012). The relationship between external job mobility and salary attainment across career stages. Journal of Vocational Behavior, 80(1), 129-136.

http://dx.doi.org/10.1016/j.jvb.2011.05.002 
Lazear, E.P. (2004). The Peter Principle: A theory of decline. Journal of Political Economy, 112(S1), S141-S163. http://dx.doi.org/10.1086/379943

Levenson, A. (2012). Talent management: challenges of building cross-functional capability in high-performance work systems environments. Asia Pacific Journal of Human Resources, 50(2), 187-204. http://dx.doi.org/10.1111/j.1744-7941.2011.00022.x

Mincer, J. (1962). On-the-job training: Costs, returns, and some implications. The Journal of Political Economy, 50-79. http://dx.doi.org/10.1086/258725

Mincer, J. (1974). Age and experience profiles of earnings. In Schooling, experience, and earnings (pp. 64-82). NBER.

Mincer, J., \& Jovanovic, B. (1981). Labor mobility and wages. In Studies in Labor Markets (pp. 21-64). University of Chicago Press.

Mincer, J. (1984). Human capital and economic growth. Economics of Education Review, 3(3), 195-205. http://dx.doi.org/10.1016/0272-7757(84)90032-3

Mion, G., \& Opromolla, L.D. (2014). Managers' mobility, trade performance, and wages. Journal of International Economics, 94(1), 85-101. http://dx.doi.org/10.1016/j.jinteco.2014.06.001

Munasinghe, L., \& Sigman, K. (2004). A hobo syndrome? Mobility, wages, and job turnover. Labour Economics, 11(2), 191-218. http://dx.doi.org/10.1016/j.labeco.2003.05.001

Murrell, A.J., Frieze, I.H., \& Olson, J.E. (1996). Mobility strategies and career outcomes: A longitudinal study of MBAs. Journal of Vocational Behavior, 49(3), 324-335. http://dx.doi.org/10.1006/jvbe.1996.0047

Neal, D. (1995). Industry-specific human capital: Evidence from displaced workers. Journal of Labor Economics, 653-677. http://dx.doi.org/10.1086/298388

Ng, T.W., Sorensen, K.L., Eby, L.T., \& Feldman, D.C. (2007). Determinants of job mobility: A theoretical integration and extension. Journal of Occupational and Organizational Psychology, 80(3), 363-386. http://dx.doi.org/10.1348/096317906X130582

Ossorio, L., \& Hunsucker, J.L. (1989). Mobility of engineers in the job market: Frequency and reasons. International Journal of Manpower, 10(3), 3-10. http://dx.doi.org/10.1108/EUM0000000000851

Powell, A., Dainty, A., \& Bagilhole, B. (2012). Gender stereotypes among women engineering and technology students in the UK: lessons from career choice narratives. European Journal of Engineering Education, 37(6), 541-556. http://dx.doi.org/10.1080/03043797.2012.724052 
Rahman, R.H.A. (2012). Malaysian firms' role in retaining engineers. The Economic and Labour Relations Review, 23(4), 57-78. http://dx.doi.org/10.1177/103530461202300405

Roosaar, L., Mõtsmees, P., \& Varblane, U. (2014). Occupational mobility over the business cycle. International Journal of Manpower, 35(6), 873-897. http://dx.doi.org/10.1108/IJM-06-2013-0130

Salleh, R., Nair, M.S., \& Harun, H. (2012). Job satisfaction, organizational commitment, and turnover intention: A case study on employees of a retail company in Malaysia. In Proceedings of World Academy of Science, Engineering and Technology (No. 72, p. 316). World Academy of Science, Engineering and Technology (WASET).

Schmutte, I.M. (2015). Job referral networks and the determination of earnings in local labor markets. Journal of Labor Economics, 33(1), 1-32. http://dx.doi.org/10.1086/677389

Sicherman, N., \& Galor, O. (1990). A theory of career mobility. Journal of Political Economy, 169-192. http://dx.doi.org/10.1086/261674

Topel, R.H., \& Ward, M.P. (1992). Job Mobility and the Careers of Young Men. The Quarterly Journal of Economics, 107(2), 439-479. http://dx.doi.org/10.2307/2118478

Vardi, Y. (1980). Organizational career mobility: An integrative model. Academy of Management Review, 5(3), 341-355.

Warn, J.R. (1994). Factors influencing the turnover of skilled personnel: A case-study. Asia Pacific Journal of Human Resources, 32(1), 29-40. http://dx.doi.org/10.1177/103841119403200103

Wright, P.M., \& Kehoe, R.R. (2008). Human resource practices and organizational commitment: A deeper examination. Asia Pacific Journal of Human Resources, 46(1), 6-20. http://dx.doi.org/10.1177/1038411107086540.

\section{Appendix}

\section{A1. Collinearity}

It is suspected that there could be collinearity issue as age and working experience are highly correlated. Correlation analysis is done and it is found that age and working experience are highly correlated $(\mathrm{r}>0.60, \mathrm{p}<.01)$. However, the Variance Inflation Factor (VIF) is less than 10 as shown in the table below, making collinearity issue to be acceptable in this context. 


\begin{tabular}{|c|c|r|r|r|r|r|r|r|}
\hline & Variables & S.D. & 1 & 2 & 3 & 4 & 5 & 6 \\
\hline 1 & Age & 5.92 & - & $0.91^{* *}$ & $0.31^{* *}$ & 0.06 & $0.59^{* *}$ & $0.16^{* *}$ \\
\hline 2 & $\begin{array}{c}\text { Working } \\
\text { Experience }\end{array}$ & 5.89 & - & - & $0.38^{* *}$ & $0.09^{*}$ & $0.64^{* *}$ & $0.17^{* *}$ \\
\hline 3 & $\begin{array}{c}\text { External Job } \\
\text { Mobility }\end{array}$ & 1.60 & - & - & - & $0.21^{* *}$ & $0.39^{* *}$ & $0.13^{* *}$ \\
\hline 4 & $\begin{array}{c}\text { Occupational } \\
\text { Mobility }\end{array}$ & 0.25 & - & - & - & 0.02 & -0.06 \\
\hline 5 & ln Earning & 0.54 & - & - & - & - & $0.14^{* *}$ \\
\hline 6 & Gender $\alpha$ & & & - & - & - & - \\
\hline
\end{tabular}

$\alpha$ Gender: $0=$ Female, $1=$ Male

${ }^{*} \mathrm{p}<.05 ;{ }^{*} \mathrm{p}<.01$

Table 4. Standard deviations and correlations of variables

\begin{tabular}{|l|r|r|}
\hline \multirow{2}{*}{ Model 3 } & \multicolumn{2}{|c|}{ Collinearity Statistics } \\
\cline { 2 - 4 } Age & \multicolumn{2}{|c|}{ Tolerance } \\
VIF \\
\hline Working Experience & .173 & 5.766 \\
\hline Gender & .144 & 6.928 \\
\hline External Job Mobility & .956 & 1.046 \\
\hline Occupational Mobility & .228 & 4.391 \\
\hline Working Experience x External Job Mobility & .945 & 1.058 \\
\hline
\end{tabular}

Table 5. Collinearity Statistics - Model 3

In collinearity diagnostics, we can see that there might be a potential issue with age and working experience. However, it is vital to include both factors as they represent different aspects of job attributes according to Klevmarken and Quigley (1976), therefore the model includes both factors in the model. 


\begin{tabular}{|c|c|c|c|c|c|c|c|}
\hline & \multicolumn{7}{|c|}{ Variance Proportions } \\
\hline & (Constant) & Age & $\begin{array}{l}\text { Working } \\
\text { Experience }\end{array}$ & Gender & $\begin{array}{c}\text { External } \\
\text { Job } \\
\text { Mobility }\end{array}$ & $\begin{array}{l}\text { Occupational } \\
\text { Mobility }\end{array}$ & $\begin{array}{l}\text { Working Experience x } \\
\text { External Job Mobility }\end{array}$ \\
\hline 1 & .00 & .00 & .00 & .01 & .00 & .00 & .00 \\
\hline 2 & .00 & .00 & .00 & .01 & .00 & .71 & .01 \\
\hline 3 & .00 & .00 & .00 & .02 & .03 & .27 & .06 \\
\hline 4 & .00 & .00 & .11 & .09 & .16 & .00 & .01 \\
\hline 5 & .01 & .00 & .00 & .86 & .07 & .02 & .04 \\
\hline 6 & .02 & .00 & .22 & .01 & .72 & .00 & .88 \\
\hline 7 & .97 & .99 & .66 & .00 & .01 & .00 & .00 \\
\hline
\end{tabular}

Table 6. Collinearity Diagnostics

\section{A2. Normality of data}

The histogram has shown the dependent variable across the sample is normally distributed, and thus suggesting the condition of normality has been met.

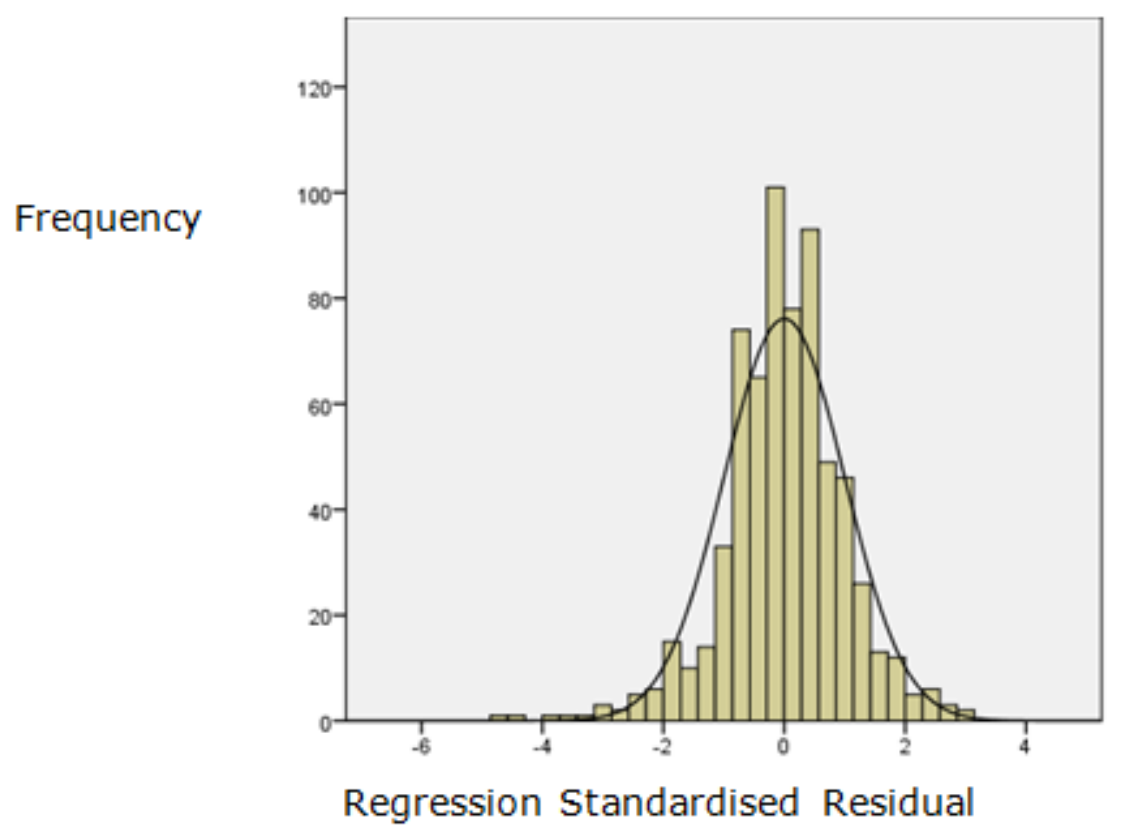

Figure 1. Histogram- Normality of dependent variable 


\section{A3. Statistical independence of error}

The standardised residual versus standardized predicted value plot is used to test the statistical independence of error. The plots are relatively scattered relatively symmetrical around zero, and thus meeting the regression condition.

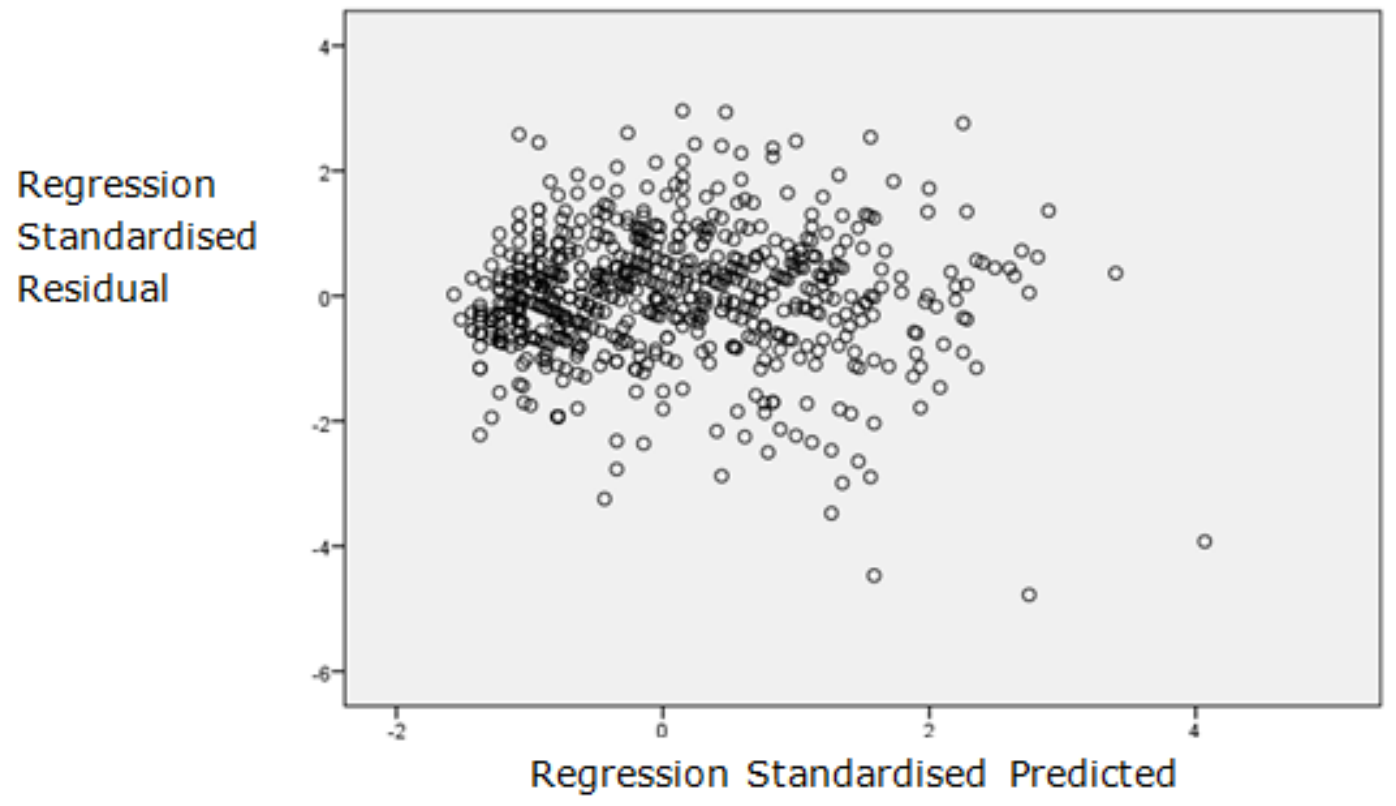

Figure 2. Standardised residual versus standardised predicted value plot

Journal of Industrial Engineering and Management, 2016 (www.jiem.org)

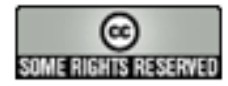

Article's contents are provided on an Attribution-Non Commercial 3.0 Creative commons license. Readers are allowed to copy, distribute and communicate article's contents, provided the author's and Journal of Industrial Engineering and Management's names are included. It must not be used for commercial purposes. To see the complete license contents, please visit http://creativecommons.org/licenses/by-nc/3.0/. 